\title{
MEASURING THE EFFECT OF THE NATIONAL CREDIT ACT ON INDEBTEDNESS IN SOUTH AFRICA
}

\author{
Shaun de Wet* \\ University of Johannesburg \\ sdewet@uj.ac.za \\ Ilse Botha" \\ Marno Booyens+ \\ University of Johannesburg \\ ilseb@uj.ac.za \\ University of Johannesburg \\ marnob@uj.ac.za \\ Received: Janaury 2014 \\ Accepted: March 2015
}

\begin{abstract}
South Africa continues to exhibit high levels of debt-to-disposable income along with a high number of impaired credit records. The National Credit Act No. 34 of 2005 (NCA) was established in order to address these high levels. This study expands the limited research by investigating the NCA's ability to reduce levels of over-indebtedness. The study employed quarterly data (2001-2013) in an OLS regression model in order to establish the determinants of over-indebtedness and assess the impact of the NCA. It was found that the macro-economic variables GDP, prime rate, property prices, consumer consumption expenditure, debt-to-disposable income and the level of unemployment were major contributors to the level of over-indebtedness. The NCA proved to have a positive significant effect on the levels of over-indebtedness, indicating that the NCA had not succeeded in its purpose of reducing the vulnerability of consumers to becoming over-indebted. The results suggest that the affordability assessment of the NCA must be improved in order to conduct a form of credit stress testing on consumers during their application for credit.
\end{abstract}

Keywords

Consumer credit, credit regulation, National Credit Act No. 34 of 2005, debt, over-indebtedness

*Mr SR de Wet is a master's student in the Department of Finance and Investment Management, University of Johannesburg, South Africa.

\#Prof I Botha is an associate professor in the Department of Finance and Investment Management, University of Johannesburg, South Africa.

+Mr M Booyens is a lecturer in the Department of Finance and Investment Management, University of Johannesburg, South Africa. 


\section{INTRODUCTION}

Consumer credit plays a major role in the financial empowerment of consumers. The availability of credit enables consumers to have the option of usage and/or ownership of an item or resource today with a delay in paying for it. Furthermore, credit enables consumers to accumulate assets over time and react to possible opportunities of arbitrage. This empowering role of credit towards a consumer also translates into faster economic growth of an economy. Although there is recognition of the advantages of consumer credit to the household sector and the overall financial and economic system, the over-usage of credit has the ability to negatively affect the consumer and the stability of an economy. The 2008 credit crisis serves as an example of how a consumer credit crisis can quickly escalate into a global financial crisis.

The South African consumer credit market and its health have been in the spotlight for a significant time. This is due to high levels of debt-to-disposable income, currently being reported at $74.5 \%$ for the second quarter of 2014 (SARB, 2014:12), and the high percentage of impaired records of total credit records, currently at $44.2 \%$ for the second quarter of 2014 (National Credit Regulator, 2014:2). Given these high levels of debt and the large number of impaired credit records, the stability of the South African credit industry must be questioned.

The major concern regarding consumers being highly indebted is their high vulnerability to becoming over-indebted. The shift from being highly indebted to being over-indebted occurs when a highly indebted consumer is presented with an unforeseen adverse external market shock and is subsequently unable to tolerate the impact, resulting in the consumer being unable to service his/her due obligations timeously. These unforeseen adverse external market shocks are viewed as adverse changes in the macro-economic environment. The state of overindebtedness, that is, the inability of a consumer "to satisfy in a timely manner all the obligations under all the credit agreements to which the consumer is a party" (South Africa (Republic), 2006:s79), has significant consequences both socially and economically. It could be argued that credit regulation has taken on the responsibility of reducing consumers from becoming highly indebted due to the adverse consequences. Consumer credit regulation is a proactive measure to prevent consumers from becoming highly indebted and thus aims to reduce the consumer's vulnerability to becoming over-indebted due to unforeseen adverse external market shocks. In order to address the high levels of over-indebtedness in South Africa, the National Credit Act No. 34 of 2005 (NCA) was established and tailored to the specific supply and demand factors that cause high levels of consumer debt in South Africa. Although, theoretically, the tailored regulation was a suitable method of reducing the high levels of consumer credit in South Africa, the literature seems to lack the empirical evidence to prove the NCA's effectiveness in its ability to prevent over-indebtedness by reducing consumers' debt load. To the authors' understanding, only two other papers (Adewale, 2014; Chipeta \& Mbululu, 2012) have investigated the influences of the NCA. Their focus was, however, on the effects of the NCA on the level of consumer credit lending and the effects on the overall economic growth; they did not investigate the NCA's ability to reduce consumers from becoming highly indebted.

This article aims to contribute to the investigation of the effects of consumer credit regulation (i.e. the NCA) by empirically testing its ability to prevent consumers from becoming highly indebted. The rest of the study is structured as follows: section 2 presents the literature review where an argument is established over the effectiveness of the NCA and thus concludes with the research problem and question. Section 3 covers the research methodology and method used to address the research objectives. Section 4 presents the results of the study. Finally, section 5 
discusses the results, and this is followed by an outlining of the limitations of the study as well as recommendations for further research.

\section{LITERATURE REVIEW}

Consumer credit is described as a tool that reduces the time frame of consumption to the present and extends the payment over time in the future (Park, 1993:28). This reduction in the time frame of consumption translates into a chain reaction of benefits. Such benefits include growth in the private sector resulting in new job creation and the ability to accumulate assets over time (Department of Trade and Industry, 2001:6). The availability and use of credit by consumers accelerates consumption in an economy, thereby amplifying the macro-economic cycle, translating into faster economic growth (Adewale, 2014:375; Fourie, Botha \& Mears, 2011:13074; INSOL, 2001:4). Despite the benefits that consumer credit provides to an economy, there is, however, its accompanying evil: the over-extension of credit to consumers.

\subsection{The shift from highly indebted to over-indebted}

The over-extension of consumer credit creates a so-called 'deviation' of credit from its previous point of equilibrium. This deviation may not be a state of disequilibrium but rather a move to a new, higher point of equilibrium, which causes an increase in the risk profile of the consumer due to this change in equilibrium. This shift in equilibrium is defined as a move from a point of low credit usage/low sensitivity, to a point of highly indebtedness/high sensitivity to adverse external events (Rinaldi \& Sanchis-Arellano, 2006:27).

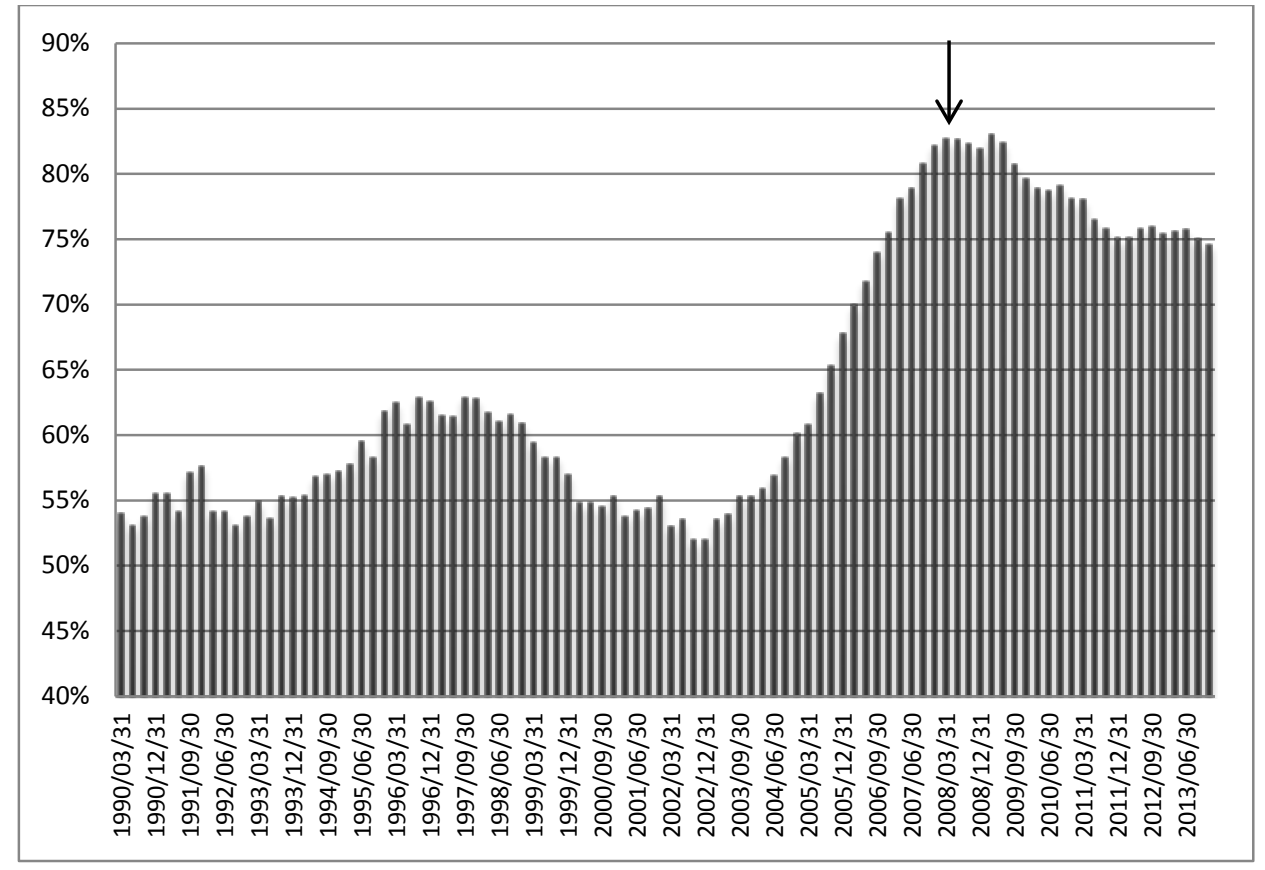

FIGURE 1: Household debt-to-disposable income ratio

Source: $\quad$ SARB, June 2014 
FIGURE 1 illustrates a major shift in the South African consumer credit risk profile. Prior to 2005 the debt-to-disposable income ratio barely exceeded the $60 \%$ mark. Since 2005 the ratio rapidly increased to its peak of $83 \%$ in the third quarter of 2009. Currently, the South African household debt-to-disposable income is $74.5 \%$, its lowest level since the third quarter of 2009 , but is still considered to be aggressive (SARB, 2014:12). The arrow in the figure indicates the stage (1 June 2007) at which the NCA came into full effect. High levels of debt will leave consumers too exposed to a range of different external market shocks, which may reduce their responsiveness to unanticipated changes in the macro-economic environment (Debelle, 2004:56; Alan, 1996:1).

These external market shocks are referred to as any external market force that has the ability to erode a consumer's/household's disposable income, thus reducing their ability to service their debt obligations. These shocks or changes in the macro-economic environment include, but are not limited to: asset price fluctuations, interest rate changes, unemployment shocks or shocks from adverse income changes and/or a rise in inflation (Meniago, Mukuddem-Petersen, Petersen \& Mongale, 2013:482; Kelly-Louw, 2009:22; Debelle, 2004:62; Aron \& Muellbauer, 2000:23).

The deterioration of the consumer/household risk profile due to the extreme amounts of debt also has a direct link to the overall financial stability of a financial system (Jappelli, Pagano \& Di Maggio, 2008:23). Credit deviations or shifts into new equilibriums expose a financial system to a variety of macro-economic imbalances such as "rising inflation, asset bubbles, inefficient booms and bursts or instabilities of a financial system" (Rubaszek \& Serwa, 2012:1).

\subsection{Rationale for consumer credit regulation}

Due to the 2008 credit crisis and its adverse effects on the global markets, supply side regulation was established in the US and other countries in order to reduce such effects on the global market and reduce the probability of such an adverse event from occurring again. South Africa, however, was more proactive in its establishment of such a regulatory framework namely the National Credit Act No. 34 of 2005 (previously the Credit Agreements Act 75 of 1980 and the Usury Act of 1968) in order to regulate the credit industry (Adewale, 2014:368). The main role of consumer credit regulation is to prevent consumers from becoming over-indebted due to the associated social and economic consequences (Simovic, Vaskovic, Rankovic \& Malinic, 2011:129). Consumer credit regulation cannot prevent the occurrence of adverse external economic events that cause consumers to become over-indebted, but it can assist in the prevention of consumers becoming highly indebted so that they may have the capacity to deal with the possible adverse change in the external market. It is thus important that the factors contributing to consumers becoming highly indebted are understood so that the correct proactive measures can be taken in order to prevent this from occurring.

\subsection{The National Credit Act No. $\mathbf{3 4}$ of $\mathbf{2 0 0 5}$ and its tailored approach}

Formally, the rationale behind the establishment of NCA in South Africa was due to the following factors that are described by the South African Department of Trade and Industry (2003:4):

- "Outdated legislation (replacing the Credit Agreements Act 75 of 1980 and the Usury Act of 1968)

- Ineffective consumer protection with particularly reference to consumers that are in the low income groups

- Limited access to credit 
- Rising levels of consumer indebtedness

- Reckless lending behaviour by credit providers and the exploitation of consumers"

Furthermore, the NCA was tailored to address the specific supply and demand factors that cause South African consumers to become highly indebted. The supply side factors include reckless lending (Department of Trade and Industry, 2001:30; Disney, Bridges \& Gathergood, 2008:28; Vessio, 2009:275; Kelly-Louw, 2009:14; Goodwin-Groen, 2006:39) and marketing of credit (Department of Trade and Industry, 2001:26; Schicks, 2010:9). The demand side factors include: financial literacy (Kotze \& Smit, 2008:170; Hurwitz \& Luiz, 2007:130; Kelly-Louw, 2008:211), disclosure and language of the credit terms (Stoop, 2009:377; Department of Trade and Industry, 2001:26), and a savings culture (Department of Trade and Industry, 2001:13; Cronje \& Roux, 2010:25).

Renke (2011) and Stoop (2009) compare the NCA measures to the supply and demand side determinants of highly indebted consumers. Both these authors are in agreement that the NCA adequately caters for the specific requirements of the credit market in South Africa (supply and demand side factors) to prevent consumers from becoming highly indebted, and are further supported by 0tto (2010:273). However, these findings need to be explored further. Both papers simply match the supply and demand determinants of high indebtedness with the NCA's ability to address them. The two papers (Renke, 2011; Stoop, 2009) therefore lack the empirical evidence to suggest that the NCA has reduced the number of consumers who have become overindebted. Others papers such as Adewale (2014) and Chipeta and Mbululu (2012) investigated the effects of the NCA on the level of consumer credit lending and the effects on the overall economic growth. These papers did not investigate the NCA's ability to reduce the risk of consumers becoming highly indebted.

\subsection{A shortcoming in the Act}

Consumer credit regulation may be there to: a) prevent consumers from becoming highly indebted and at the same time $b$ ) encourage consumer credit extension. These two purposes seem, at face value, to be contradictory to each other (keep debt levels down but at the same time increase debt extension), and it is in this contradiction that there seems to be a shortcoming in the NCA.

\subsubsection{The contradiction}

Braucher (2006:5) describes regulation as a structural factor that may possibly increase (deregulation) or decrease (stricter regulation) the supply of credit. This links with Rinaldi and Sanchis-Arellano's (2006:4) proposal that structural supply side factors including regulation "play a role in determining the stability of financial conditions and therefore the equilibrium level of household debt" (Rinaldi \& Sanchis-Arellano, 2006:4). From these two suggestions one can deduce that regulation may in fact decrease or increase the level of debt that consumers may take on. Schicks $(2010: 8)$ is also in agreement with this. The institutional and legal environment of a credit system influences the behaviour of both the demand and supply of consumer credit. This influence may either be to the advantage or detriment of either side. For example, it can be argued that a new form of regulation must be viewed as a form of a financial development or an improvement of a financial system. This development and liberalisation of a financial sector may contribute to increasing usage of consumer credit (Nieto, 2007:11). In this context regulation becomes a supply side factor that pushes consumers to a higher debt level. 
However, considering that credit is required to accelerate economic growth (Adewale, 2014:375; Fourie et al., 2011:13074; INSOL, 2001:4), it may be suggested that if regulation encourages: a) healthy credit extension into an economy, b) healthy competition in an economy and c) assists in reduction of the probability of consumers becoming too highly indebted, then such a notion may be supported.

The notion of regulation to 'encourage consumer credit extension' should not be interpreted as an increase in the volume of credit. Naturally, greater access of credit to a wider population will increase the volume of credit granted, but this volume of credit should be within the income or affordability levels of the population. All consumers are encouraged to have access to healthy credit limits. That household debt-to-disposable income in South Africa is $74.5 \%$ (SARB, 2014:12) may suggest that there are unhealthy debt levels in South Africa. This correlates with the lifecycle theory of Modigliani and Brumberg (1954), where the high debt-to-income ratio is possibly justifiable due to the very young population that is attempting to smooth their consumption over the course of their lives. If this section of the population (which is the majority of the South African population at an average age of 25 years) (STATS SA, 2011) is able to deal with adverse external market shocks and still maintain their minimum household expenditure, the high household debt levels may not be a major concern, especially if the debt is used to accumulate assets such as property (Keese, 2009:4; Compliance and Risk Resources, 2012:29).

\subsubsection{The shortcoming: The timing of the affordability assessment}

The missing empirical evidence from the two conclusions of Renke (2011) and Stoop (2009) (who concluded that the NCA adequately caters for the specific requirements of the credit market in South Africa (supply and demand side factors) to prevent consumers from becoming highly indebted) lies in determining whether consumers can maintain their minimum levels of household expenditure and credit affordability when adverse external shocks occur. If South African consumers are able to maintain credit affordability when adverse external market conditions are presented, or at least are more able to do so after the establishment of the NCA, then the NCA has aided in the prevention of over-indebtedness.

This is addressed in sections 80 to 82 of the NCA, whereby a consumer may be granted a requested amount of credit if the consumer has been through an adequate financial assessment known as an affordability assessment, which is described as a cornerstone of the NCA (Compliance and Risk Resources, 2012:27). The problem lies in the timing of when the affordability assessment is conducted by the credit provider. The outcomes of the affordability assessment are determined by the prevailing macro-economic conditions, more specifically, the interest rates at that specific time (Kelly-Louw, 2009:13). Research indicates (Kelly-Louw, 2009:13; Compliance and Risk Resources, 2012:36) that the affordability assessment does not take into account the sensitivity of the consumers' disposable income if any adverse external market event were to occur. For example, Kelly-Louw (2009:13) focused on the sensitivity of interest rate changes and suggests that lower-class consumers tend to lose their homes due to their inability to absorb higher payments due to increases in the interest rates. The NCA does take interest rate volatility into account as a cause of over-indebtedness. The regulations of Banks do complement the NCA by providing a cap on the interest rates over the rate of interest charged by credit providers on credit lent to consumers. However, this capped interest charged by credit providers is based on the prevailing repo rate provided by the South African Reserve Bank (SARB), which is not capped. Consequently, any factor that influences or changes the 
disposable income of a consumer negatively may then influence the consumer's ability to honour his or her debt obligations as they become unmanageable (Schicks, 2010:14). Thus, macro-economic developments may increase a consumer's vulnerability to becoming overindebted.

This vulnerability of consumers to macro-economic variables can further be explained by papers such as those of Bofondi and Ropele (2011:22), Louzis, Vouldis and Metaxas (2011:14) and more specifically Havrylchk (2010:25), which show that a change in macro-economic variables does have a significant effect on the quality of bank loans and the level of non-performing loans. Credit providers, namely banks, are required by Basel II to conduct stress testing on their loans in order to assess the risk exposure of their assets. This is due to the fact that a change in the macro-economic state affects a consumer's ability to service his or her debt obligations, thus resulting in the credit assets becoming risky, and, in a worst-case scenario, worthless. The change in macro-economic variables in these particular cases is the view from a credit provider's perspective and not that of a consumer. Thus, due to the limitation of the NCA stressed by Kelly-Louw (2009:13) it may be asked: why is stress testing not done on consumers when they apply for credit?

Although there is a theoretical agreement (Renke, 2011; Stoop, 2009 \& 0tto, 2010) on the tailored ability of the NCA to prevent consumers from becoming highly indebted, a limitation in the NCA has been identified: it does not contain any form of affordability stress testing that credit providers should conduct on consumers who are applying for credit (Kelly-Louw, 2009). Despite this contradiction in the NCA's ability, neither of the two views (Renke, 2011; Stoop, 2009; 0tto, 2010 versus that of Kelly-Louw, 2009) provides empirical evidence to support their views on the NCA's ability in preventing consumers from becoming highly indebted.

The purpose of this study is to investigate whether the NCA has succeeded in reducing consumers' vulnerability to becoming over-indebted due to changes in the macro-economic environment. Empirical evidence was therefore collected to measure the change in consumers' vulnerability to becoming over-indebted due to adverse external market shocks, (pre- versus post-implementation of the NCA, 1 June 2007) with the aid of a statistical model.

\section{METHODOLOGY}

\subsection{Data type and sourcing}

Time series macro-economic variables were obtained from the SARB, ABSA Group Limited and the International Monitory Fund (IMF). All variables used are in quarterly time series from the period January 2001 to December 2013. The study period selected is justified by the fact that the selected period represents the required macro-economic cycle in the South African economic environment. A macro-economic cycle is required in order to capture the full effects that the independent variables, at different levels, may have on the dependent variable.

\subsection{Dependent variable}

The study requires a specific dependent variable that measures the number of over-indebted consumers in South Africa over the required study period ranging from 2001 to 2013. The National Credit Regulator (NCR) records on quarterly bases the total number of impaired consumers as a percentage of the total credit-active consumers of all credit providers (bank 
and non-bank) in South Africa (National Credit Regulator, 2014:2). The limitation of this specific measurement is that the data series exists only from June (quarter 2) 2008, when the NCA came into full effect. Due to this lack of data (pre- and post-NCA), a proxy of overindebtedness needs to be established to fill its role.

Overdue loans as a percentage of total loans may serve as a viable proxy for the level of overindebtedness due to the similar characteristics of the two variables. The numerator of the 'impaired consumers as a percentage of the total credit-active consumers' from the NCR consists of any consumer who has not served his or her debt obligation(s) within a certain specified period of days. More specifically, the time period is "three or more payments or months in arrears" (National Credit Regulator, 2014:8). The same can be said for banks, as the numerator of the 'Rand value of overdue loans as a percentage of total loans' are loans that have been overdue for a specific period of days. However, the form of disclosure of the numerator (Rand value of overdue due loans) has undergone a number of regulatory changes during the required study period (2000-2013) and must therefore be addressed.

Post-2001, banks were required to disclose total overdue loans, which were divided into three sub-overdue loan categories namely: 0-1 month, 1-3 months and longer than 3 months. The 'overdues as a percentage of advances' included these three subcategories (SARB, 2000:113). From 2001 to 2007 there was a change in the disclosure of overdue loans, which were then divided into four new subcategories, namely: 'special mention' ( $>30$ to 90 days overdue), 'substandard' ( $>90$ to 180 days overdue), 'doubtful' (>180 days to 1 year overdue) and 'loss' (>1 year overdue). This disclosure was known as the DI500 credit risk. The 'overdues as percentage of advances' reported from 2001 to 2007 only included loans falling within the definitions of 'doubtful' and 'loss' - i.e. any loan overdue by more than 180 days (SARB, 2001:62). From 2008 there was a complete shift in the disclosure of credit risk by banks due to the introduction of Basel II. Basel II required banks to report on 'total impaired advances', which replaced the previously disclosed overdue loans (the sum total of doubtful and loss) that was required during the period of 2001 to 2007. The term 'impaired advances' is defined in the regulations relating to banks as when "objective evidence exists that the bank is unlikely to collect the total amount due" (South Africa (Republic), 2012:378), or, more specifically, "an advance against which specific credit impairment has been raised" (SARB, 2008:66).

This definition of impaired advances resulted in the inclusion of a much larger overdue loans population than according to the previous definition of overdue loans (the sum of doubtful and loss) between the years 2001 to 2007. It can therefore be assumed that during the study period required (2001 to 2013) there was one structural change. The dependent variable will then consist of the following two variables:

- 2001 to 2007: 'overdues as percentage of advances' included all loans overdue by 180 days

- 2008 to 2013: 'Impaired advances to gross loans and advances' included all loans where any credit impairment was raised.

\subsection{Independent variables}

Consumers move from a state of highly indebted to over-indebted by dint of adverse external macro-economic events that may negatively influence their ability to service their debt obligations. Thus, the establishment of the macro-economic independent variables is justified by the fact that any change in the macro-economic variables may influence consumers' disposable income to such an extent that they can no longer meet their credit obligations, i.e. 
the consumer moves from being highly indebted to being over-indebted. Macro-economic variables are sourced from the findings of papers that have investigated the influence of these variables on consumer credit risk. The variables are categorised under four sections as follows: general level of economic activity, price stability, the state of consumer's households and capturing the effects of the structural break, 2008 credit crisis and NCA.

\subsubsection{The first category: the general level of economic activity}

GDP:

The feature of GDP is that it has a direct influence on the affordability of credit. Generally, high levels of GDP will represent strong flows of income to consumers. Furthermore, high levels of GDP will encourage credit usage. When GDP declines, low levels of credit demand are expected, with an accompanying decrease in income, thus reducing the affordability of credit to consumers previously obtained during high levels of GDP and leading to increased levels of default. Thus it is expected that there will be a negative correlation between GDP and over-indebted consumers. (Bofondi \& Ropele, 2011:11; Arpa et al., 2001:97; Havrylchyk, 2010:11; Kalirai \& Scheicher, 2002:64; Louzis et al., 2011:14; Shu, 2002:6; Virolainen, 2004:15; Zeman \& Jurac, 2008:10; Chipeta \& Mbululu, 2012:223; Meniago et al., 2013:488).

\subsubsection{The second category: price stability indicators}

Inflation:

Inflation (CPI) has elicited conflicting views from researchers. The level of inflation will influence a consumer's purchasing power and thus directly affect the consumer's level of disposable income. However, it could also be that inflation may assist consumers in repaying their loans, as their disposable income may grow with inflation but the loan amount will remain the same as the years pass. Despite the different potential effects, it is expected that inflation will generally have a positive relationship on the level of over-indebtedness due to its eroding effects on a consumer's disposable income (Bofondi \& Ropele, 2011:1; Havrylchyk, 2010:11; Kalirai \& Scheicher, 2002:66; Rinaldi \& Sanchis-Arellano, 2006:14; Shu, 2002:6; Zeman \& Jurac, 2008:10; Meniago et al., 2013:488).

\section{Prime rate:}

The prime rate is a direct cost of borrowing and therefore has a significant influence on the affordability to a consumer of any loan that is subject to interest fluctuations. This is particularly important, as the majority of consumer loans are at a floating rate to the prime rate provided by the reserve bank. A rise in the prime rate will increase the services burden on consumers, resulting in a highly indebted consumer becoming over-indebted. It is expected that there will be a positive relationship between the prime rate and the level of over-indebtedness (Bofondi \& Ropele, 2011:12; Arpa et al., 2001:97; Havrylchyk, 2010:11; Louzis et al., 2011:14; Rinaldi \& Sanchis-Arellano, 2006:14; Shu, 2002:6; Virolainen, 2004:15; Chipeta \& Mbululu, 2012:223; Meniago et al., 2013:488). 


\subsubsection{The third category: the state of consumers' households}

Property prices:

Property prices are significant, as they serve as collateral for many forms of debt. Firstly, higher property prices are accompanied by higher levels of debt repayment due to the significant wealth gains. However, a decline in property prices to the point that it exceeds the value of the mortgage may encourage consumers to neglect paying their debt. Secondly, as learnt from the 2008 credit crisis, an increase in property prices may provide for mortgage or loan renegotiation, thus making debt more affordable and reducing the probability of default. Again, however, there are conflicting views on this second point: an increase in property prices may encourage consumers to increase the amount of debt incurred (and thus their probability of defaulting), as there is more collateral to guarantee this debt. Therefore, it is expected that there will be a positive relationship between property prices and the level of over-indebtedness (Bofondi \& Ropele, 2011:12; Arpa et al., 2001:97; Havrylchyk, 2010:12; Shu, 2002:6; Meniago et al., 2013:488).

\section{Consumer consumption expenditure:}

High levels of consumer consumption are expected to reduce the ability of consumers to repay their debt. It is expected that there will be a positive relationship between overall consumption levels and the level of over-indebtedness (Havrylchyk, 2010:12; Meniago et al., 2013:488).

Debt-to-disposable income ratio:

The higher level of debt-to-disposable income may reduce the probability that the consumer will service his or her debt obligations. The higher the debt burden on a consumer, the higher the probability of the consumer not meeting his or her debt payments, as economic conditions worsen. A positive relationship between debt-to-disposable and the level of over-indebtedness is thus expected (Bofondi \& Ropele, 2011:12; Rinaldi \& Sanchis-Arellano, 2006:14).

Level of unemployment:

The changing levels of unemployment are said to have a direct influence on the affordability of any debt. Therefore, in the case of the unemployment of a consumer, he or she will become overindebted due to his or her inability to continue servicing his or her credit; therefore a positive relationship is expected (Bofondi \& Ropele, 2011:11; Havrylchyk, 2010:12; Kalirai \& Scheicher, 2002:66; Louzis et al., 2011:14; Rinaldi \& Sanchis-Arellano, 2006:16; Shu, 2002:6).

\subsubsection{The fourth category: capturing the effects of the structural break, 2008 credit crisis and NCA}

Accounting for the structural break in the dependent variable (SDUM):

A dummy variable will be introduced into the model to account for the change in definition of impaired loans (structural break) between 2007 and 2008 (Arpa et al., 2001:97).

Accounting for the 2008 credit crisis (CDUM):

A second dummy variable will be introduced for the period September 2008 ( 03 ) to December 2009 (Q4) to account for the effect of the 2008 credit crisis on the levels of over-indebtedness (Chipeta \& Mbululu, 2012). It is expected that there will be a positive relationship during the 
credit crisis period, as the crisis had an overall negative effect on the economy, thus negatively affecting consumers' ability to service their loans.

Capturing the effect of the NCA (NDUM):

In order to capture the pre- and post-effect of the NCA on overdue loans, a dummy variable will be introduced. The NDUM variable will capture the effects of the macro-economic conditions on the levels of over-indebtedness after the introduction of the NCA (September, Q3 2007), (Chipeta \& Mbululu, 2012). Although it is stated by Renke (2011) and Stoop (2009) that the NCA was tailored to reduce consumers from becoming highly indebted and thus reduce the number of over-indebted consumers, it is expected that the NCA will have an overall negative effect on the level of over-indebtedness. This is justified by the limitation in the affordability assessment found by Kelly-Louw (2009).

\subsection{Empirical model}

In order to achieve the research goal of identifying the determinants of over-indebtedness, a suitable model must be selected to elucidate the relationship between the dependent variable and a series of independent variables. Thus, the Ordinary Least Squares (OLS) regression method will be employed. The use of the OLS regression method will enable the use of certain tests and the introduction of dummy variables to account for the effects of the NCA on overindebtedness. Papers that employ the OLS regression model include bank credit stress testing (Kalirai \& Scheicher, 2002; Zeman \& Jurac, 2008; Havrylchyk, 2010), bank risk provisions (Arpa, Giulini, Ittner \& Pauer, 2001), bank loan quality (Bofondi \& Ropele, 2011; Shu, 2002) and determinants of credit demand (Chipeta \& Mbululu, 2012). In justifying the use of the OLS regression method, the above bank credit stress testing, bank risk provisions and bank loan quality papers all employ the OLS regression model to regress a series of macro-economic determinants to their specific dependent variable in order to establish a relationship.

The complete function of the model can be presented as follows:

$$
\begin{aligned}
& 0 D P O_{t}=\beta_{1} L O G(G D P)_{t}+\beta_{2} C P I_{t}+\beta_{3} P R_{t}+\beta_{4} L O G(C O N S)_{t}+\beta_{5} D D I_{t}+\beta_{6} U E M_{t}+\beta_{7} S D U M_{t}+\beta_{8} C D_{U M}+ \\
& \beta_{9} N{ }^{\prime} M_{t}+\varepsilon_{t}
\end{aligned}
$$

Where:

ODPO: = Level of over-indebtedness where 2001-2007: 'Overdues as percentage of advances' and 2008-2013: 'Impaired advances to gross loans and advances'

$\operatorname{LOG}(G D P)=$ The natural log of real GDP

$\mathrm{CPI} \quad=$ Consumer price index

$\mathrm{PR} \quad=$ Real prime rate

$\operatorname{LOG}(\mathrm{PP}) \quad=$ The natural log of the ABSA household index

LOG(CONS) $=$ The natural log of real household consumption expenditure

DDI = The household debt-to-disposable income ratio

UEM = The level of unemployment as a percentage 
De Wet, Botha \& Booyens

SDUM = Structural change dummy variable

CDUM = Credit crisis dummy variable

NDUM = NCA dummy variable

\section{RESULTS}

\subsection{Correlation analysis of the variables}

TABLE 1 illustrates the results of the correlation between the dependent and independent variables.

TABLE 1: Correlation among variables, 2001-2013

\begin{tabular}{|c|c|c|c|c|c|c|c|c|}
\hline & ODPO & $(L O G) G D P$ & $C P I$ & $P R$ & $(L O G) P P$ & (LOG)CONS & $D D I$ & UNE \\
\hline ODPO & 1.00 & 0.45 & 0.06 & -0.38 & 0.33 & 0.43 & 0.33 & 0.04 \\
\hline$\angle G D P$ & & 1.00 & 0.08 & -0.65 & 0.97 & 1.00 & 0.90 & -0.62 \\
\hline$C P I$ & & & 1.00 & 0.63 & 0.00 & 0.05 & 0.21 & -0.07 \\
\hline$P R$ & & & & 1.00 & -0.65 & -0.67 & -0.42 & 0.30 \\
\hline$\angle P P$ & & & & & 1.00 & 0.97 & 0.92 & -0.69 \\
\hline LCONS & & & & & & 1.00 & 0.89 & -0.63 \\
\hline$D D I$ & & & & & & & 1.00 & -0.78 \\
\hline UNE & & & & & & & & 1.00 \\
\hline
\end{tabular}

Source: Eviews 8, Authors' analysis

There is a positive, weak to moderate relationship between the independent variable and the dependent variables (first row of the table). However, the prime rate (PR) indicates a negative, moderately weak $(r=-0.38)$ relationship. The inflation (CPI), property prices ((LOG)PP), consumer consumption expenditure ((LOG)CONS), debt-to-disposable income (DDI) and unemployment $(U N E)$ variables have positive relationships and are all in line with the expected outcomes. However, the gross domestic product's ((LOG)GDP) positive relationship is not in line with the expected results.

The debt-to-disposable income (DDI) variable has a high correlation with four other independent variables, namely gross domestic product ((LOG)GDP), property prices ((LOG)PP), consumer consumption expenditure ((LOG)CONS) and unemployment (UNE). There is a high correlation between property prices (LOG)PP and gross domestic product (LOG)GDP. This suggests the presence of multicollinearity among the explanatory variables. However, the correlation matrix is not a good measurement for multicollinearity if there are more than two independent variables (Montgomery, Peck \& Vining, 2001:7-6). The undesirable state of multicollinearity occurs when there is a linear relationship among some or all of the independent variables (Gujarati \& Porter, 2009:321). There are generally two main options to address multicollinearity: the first is to remove some of the highly correlated independent variables, and the second to do nothing (Gujarati \& Porter, 2009:342). In this case it was decided not to remove 
any explanatory variables, since it is imperative for the analysis to include all the variables in the function. Furthermore, such variables causing multicollinearity are used only as control variables and thus may not impact the performance of the model (Allison, 2012).

The VIF (TABLE 2) indicates how much the variance of the coefficient estimate is being inflated by multicollinearity. A VIF close to 1 suggests that there is no multicollinearity, while a VIF near 5 (and above) may cause concern (Montgomery, et al., 2001:7-7).

\section{TABLE 2: Variance Inflation Factors}

\begin{tabular}{ll}
\hline Variable & $\begin{array}{l}\text { Coefficient } \\
\text { Variance }\end{array}$ \\
\hline C & 2152.47 \\
LOG(GDP) & 309.49 \\
\hline LOG(PP) & 1.05 \\
PR & 0.01 \\
\hline DDI & 0.00 \\
\hline UNE & 0.00 \\
\hline LOG(CONS) & 268.47 \\
\hline
\end{tabular}

Source: Eviews 8, Authors' analysis

The VIF (TABLE 2) indicates that most of the multicollinearity is caused by the LOG(GDP) and LOG(CONS) variables, which are both control variables. CPI was removed due to its insignificance in the final model.

\subsection{Accounting for the structural break in the data}

The final proxy chosen for over-indebtedness presented a limitation that must be taken into account. The definition of the data collection method of overdue loans to total loans and advances changed over the study period. TABLE 3 provides the descriptive analysis between the two definitions.

TABLE 3: Descriptive analysis of the independent variable

\begin{tabular}{lrrr}
\hline & & & $2008-2013$ \\
\hline Mean & 2.16 & Mean 2007 & 4.63 \\
Median & 2.00 & Median & 4.62 \\
Maximum & 3.70 & Maximum & 5.93 \\
Minimum & 1.10 & Minimum & 2.17 \\
Std. Dev. & 0.85 & Std. Dev. & 1.12 \\
\hline Observations & 28.00 & Observations & 24.00 \\
\hline
\end{tabular}

Source: Eviews 8, Authors' analysis 
In a comparison of the means between the two definitions in TABLE 3 (2001-2007: 2.16 versus 2008-2013: 4.63), it is clear that there was a change in the definition that influenced the size of the population. After conducting the Chow Forecast test to detect the presences of structural changes in the data, the $p$-value of the $F$-statistic was .00 , thus indicating a rejection of the null hypothesis (if $p$-value $<.05$ we reject the $\mathrm{H}_{0}$ ). One should therefore account for the structural break by adding a dummy variable to the function.

The regression was constructed by adding a dummy variable for the structural break (SDUM). Second-order diagnostics indicated that autocorrelation and heteroscedasticity were present. After correcting for autocorrelation and heteroscedasticity with the Newey-West test, all independent variables remained significant, with inflation (CPI) and unemployment (UNE) proving to be insignificant. As the dummy variable (SDUM) indicated that there was not a significant structural break in the model, it was removed. The insignificance of the SDUM variable may be due to the definition only changing in terms of the size of the population.

\subsection{Accounting for the credit crisis}

During the study period, an economic crisis occurred, which may have had an effect on the explanation of the dependent variable. Thus, an account of the effect of the 2008 credit crisis on the levels of over-indebtedness must be considered. A credit crisis dummy was added to the regression. Second-order diagnostics indicated that autocorrelation was present. After correcting for autocorrelation using the Newey-West test, all independent variables remained significant, with inflation ( $\mathrm{CPI}$ ) and the credit crisis dummy variable remaining insignificant. The CDUM dummy variable presented a $p$-value greater than .05 , indicating that the crisis did not have a significant effect on the levels of over-indebtedness. This insignificant result may be due to the stronger consumer credit regulatory environment in South Africa that had limited the effects of the 2008 credit crisis on the consumer credit system. Due to the insignificance, the credit crisis dummy was removed.

\subsection{Accounting for the NCA}

Finally, a dummy variable was added to the model to account for the changes in the independent variable due to the NCA. Second-order diagnostics indicated the presence of autocorrelation and heteroscedasticity. After correcting for autocorrelation and heteroscedasticity the NDUM dummy variable remained significant at a $90 \%$ confidence level. The macro-economic explanatory variables, LOG(GDP), PR, LOG(PP), LOG(CONS) and DDI, remained significant at a $99 \%$ level of confidence, and UNE was significant at a $95 \%$ level, while inflation ( $\mathrm{CPI}$ ) remained insignificant. Due to the inflation ( $\mathrm{CPI}$ ) variable still remaining insignificant, it was removed from the final model. TABLE 4 presents the final model. 
TABLE 4: Results after Newey-West test (excluding inflation (CPI))

\begin{tabular}{lcccc}
\hline Variable & Coefficient & Std. Error & t-Statistic & Prob. \\
\hline C & -401.18 & 138.29 & -2.90 & 0.01 \\
LOG(GDP) & $113.22 \star \star \star$ & 33.65 & 3.36 & 0.00 \\
PR & $-0.58 \star \star \star$ & 0.13 & -4.39 & 0.00 \\
LOG(PP) & $-9.10 \star \star \star$ & 1.80 & -5.04 & 0.00 \\
LOG(CONS) & $-84.69 \star \star \star$ & 25.17 & -3.37 & 0.00 \\
DDI & $0.15 * \star \star$ & 0.04 & 3.85 & 0.00 \\
UNE & $0.18 * \star$ & 0.09 & 2.10 & 0.04 \\
NDUM & 1.43 & 0.88 & 1.62 & 0.11 \\
\hline R-squared & 0.87 & Mean dependent var & 3.30 \\
Adjusted R-squared & 0.85 & S.D. dependent var & 1.58 \\
F-statistic & 41.75 & Wald F-statistic & 29.91 \\
Prob(F-statistic) & 0.00 & Prob(Wald F-statistic) & 0.00 \\
\hline Source:Evews 8 authors &
\end{tabular}

Source: Eviews 8 , author's analysis

$\star * \star, * *, *$ indicate significance at the $1 \%, 5 \%$ and $10 \%$ levels respectively

The NDUM dummy variable became significant at a lower $89 \%$ confidence level from the previous $90 \%$ confidence level once CPI was removed. This is a marginal change. The macro-economic explanatory variables, gross domestic product ( $L O G(G D P))$, prime rate (PR), property prices (LOG(PP)), consumer consumption expenditure (LOG(CONS)) and debt-to-disposable income (DDI) remained significant at a $99 \%$ level of confidence. Unemployment (UNE) was significant at a $95 \%$ level. The debt-to-disposable income (DDI) and unemployment's (UNE) positive relationships are in line with the expected results. However, gross domestic product's (LOG(GDP)) positive relationship, as well as prime rate (PR), property prices (LOG(PP)) and consumer consumption expenditure's (LOG(CONS)) negative relationships are not in line with the expected results.

These contradictions to the expected relationships may be ascribed to a number of reasons. The gross domestic product's ((LOG)GDP) positive relationship may suggest that as economic activity increases consumers may take on such a large portion of debt (due to the expectations of increasing income) that they become over-indebted. A second reason may be that, for example, during an economic upswing, consumers may spend large amounts of their disposable income to such an extent that there is not enough disposable income to service their debt obligations anymore. However, the spending is reduced in a downswing; therefore income is made available for debt servicing. The prime rates' (PR) negative relationship may indicate that consumers may not be sensitive to increased rate changes or consumers may be taking out secondary unsecured loans to cope with the increase in payments on their primary loans. The property prices' ((LOG)PP) negative relationship may indicate that consumers could be refinancing their loans to the increased value of the assets, making credit more affordable. Or secondly, consumers may be taking advantage of the property cycle by selling off their assets during an asset price increase, to pay back their credit. Consumer consumption expenditure's 
(LOG(CONS)) negative relationship, being contradictory to the expected outcome, may indicate that consumers do not reduce the proportion of income to service their debt when consumption increases. These relationships are discussed in detail in the discussion section. The final explanatory power of the model remained high, with an adjusted $R^{2}$ of 0.85 . The F-statistic, testing the overall significance of the regression model, indicates that the explanatory variables jointly explain the dependent variable with a $p$-value of .00 .

The final model presented in TABLE 4 contains the significant macro-economic determinants of over-indebtedness in South Africa. These macroeconomic determinants of over-indebtedness are as follows: gross domestic product (LOG(GDP)), prime rate (PR), property prices (LOG(PP)), consumer consumption expenditure (LOG(CONS)), debt-to-disposable income (DDI) and unemployment (UNE). Furthermore, the final model presented in TABLE 4 also successfully accounts for the effect of the NCA on the levels of over-indebtedness.

\section{DISCUSSION OF RESULTS}

The findings can be grouped under three main themes: the structural break of the dependent variable, the influence of the 2008 credit crisis and the effects of the NCA.

\subsection{The structural break}

The Chow forecast test indicated that the structural break was significant and therefore needed to be accounted for in the model. After the addition of the structural dummy variable (SDUM) from $2008 \mathrm{Ql}$ and correcting for the presence of autocorrelation and heteroscedasticity, the SDUM proved to be insignificant. This may be as a result of both definitions' denominators remaining relatively similar by definition. However, the numerators changed only in their population size. There was an expansion of the definition for overdue loans that was reported from 2001 to 2007 (which included loans overdue by 180 days) to impaired advances (which included all loans that had risen an impairment irrespective of the time frame) that was reported from 2008 to 2013.

\subsection{The influence of the $\mathbf{2 0 0 8}$ credit crisis}

The credit crisis occurred shortly after the implementation of the NCA. It was expected that the credit crisis would bring about an increase in the level of over-indebtedness, as it had a negative effect on the economy. After correcting for autocorrelation, the CDUM proved to be insignificant. The credit crisis did not negatively influence the macro-economic environment of South Africa to such an extent that it caused consumers to become over-indebted (South Africa (Republic), 2011:13). Furthermore, it was suggested by the Department of National Treasury that the updated consumer credit regulatory environment (namely the implementation of the NCA) in South Africa had helped consumers avoid being negatively affected by the 2008 credit crisis (South Africa (Republic), 2011:13).

\subsection{The effects of the NCA}

Finally, after removing the credit crisis dummy due to its insignificance, a dummy variable was introduced into the model to assess what the effects of the NCA on the levels of overindebtedness were after its implementation. After removing the CPI variable (due to its 
insignificance) and correcting for the presence of autocorrelation and heteroscedasticity, the NDUM proved to be significant. The relationship proved to be positive, suggesting that the NCA has not been able to reduce consumers from becoming over-indebted.

There are four main themes that may aid in an explanation of this positive relationship. Firstly, Kelly-Louw (2009:23) and the report to the National Credit Regulator (NCR) (Compliance and Risk Resources, 2012:36) indicate that a major limitation of the NCA is that there is no form of stress testing in the affordability assessment of the NCA. Thus, the NCA may have failed to take into account the future affordability of proposed credit to consumers when there is an adverse change in the macro-economic environment. Secondly, the report to the NCR (Compliance and Risk Resources, 2012:14) indicates that credit providers still seemed to lend recklessly by not conducting the affordability assessments accurately and the NCA therefore played a limited role in preventing consumers from taking on large amounts of debt. Thirdly, after the establishment of the NCA a large gap in the credit lending market opened up (the unsecured lending market). Due to the limited assessment criteria required by the NCA for unsecured loans, the NCA may have failed in its ability to prevent consumers from becoming highly indebted through the use of unsecured lending (Adewale, 2014:371). Lastly, there may have been a large population of already highly indebted consumers who were in the South African credit system before the implementation of the NCA. The majority of the credit population may still have been adversely affected by macroeconomic changes. The true effects of the NCA on the levels of overindebtedness may possibly take a while to surface through the consumer credit system of South Africa.

The overall explanatory power of the independent variables in the final model proved to be high. GDP indicated a positive significant relationship. However, this was in contradiction to the expected outcome of a negative relationship between GDP and over-indebtedness as well as to the findings of Havrylchyk (2010:15). There are two possible reasons why this contradiction occurred. Firstly, it may be due to consumers taking out more credit as their current (and expected) level of income increased, thus ultimately leading to the state of over-indebtedness. This logic is supported by the findings of Meniago et al. (2013:488), where it was proposed that household debt increases concurrent with a rise in GDP. However, such reasoning is not in agreement with Chipeta and Mbululu (2011:223), who found that there is an inverse relationship between GDP and credit demand, thus indicating that consumers do not borrow more when they earn more. The second possible explanation for the positive significant relationship between over-indebtedness and GDP may be formulated as follows: as GDP increases, consumers spend more, thus reducing their portion of disposable income to service their debt. This suggestion could then be confirmed by a positive relationship between consumer consumption expenditure and over-indebtedness. However, the levels of consumer consumption expenditure indicated a negative significant relationship. This outcome was not in support of the expected outcome, but was indeed supportive of the findings of Havrylchyk (2010:15). This suggests that high levels of consumption may not reduce the disposable income available to consumers to meet their debt obligations.

The debt-to-disposable income and unemployment proved to be positive and significant, which was in support of the expected outcome. Both the state of high levels of debt and the state of unemployment have a direct impact on the levels of over-indebtedness (Bofondi \& Ropele, 2011:22; Rinaldi \& Sanchis-Arellano, 2006:26; Kalirai \& Scheicher, 2002:68; Louzis et al., 2011:14 \& Havrylchyk, 2010:15). 
The prime rate indicated a negative significant relationship. This was in contradiction of the expected outcome of a positive relationship and also in disagreement with the findings of Havrylchyk (2010:15). This may possibly indicate that consumers take out more loans (especially in the form of unsecured loans) (Developmentnomics, 2012:58) in order to meet the increase in the servicing of their current loans. This is supported by Chipeta and Mbululu (2011:223), who found that there is an inverse relationship between interest rates and credit demand in South Africa.

Property prices showed a negative significant relationship, which was not in line with the expected positive relationship, but is in agreement with the findings of Bofondi and Ropele (2011:22) and Havrylchyk (2010:15). This negative relationship may possibly be explained by two factors. Firstly, when the asset base of consumers increases due to the increase in property prices, consumers reduce their probability of becoming over-indebted by not taking out more debt. Secondly, consumers may use the property cycle to their advantage: they may settle their outstanding debt by selling off their property when the property prices are favourable.

Finally, CPI proved to be insignificant. This insignificant result may suggest that inflation may erode a consumer's disposable income slowly. Thus inflation may not have such a significant effect (or shock) on a consumer's disposable income that it will cause a highly indebted consumer to become over-indebted. Another possible reason for this outcome is that South Africa has had a history of high levels of inflation, and therefore the sensitivity that consumers have to inflation is somewhat minimal.

\section{CONCLUDING REMARKS AND POSSIBLE AREAS FOR FURTHER RESEARCH}

This study contributes empirical evidence of the National Credit Act's (NCA) attempt to reduce the level of over-indebtedness in South Africa. It was assumed that if consumers are highly indebted and an external market shock occurs, they may find themselves being unable to service their due obligations and have thus reached the state of over-indebtedness. Consumer credit regulation may thus not be able to reduce the effects of adverse external market shocks but may reduce the level of debt a consumer takes on, therefore reducing a consumer's vulnerability to adverse external market shocks.

It was found that the macro-economic explanatory variables GDP, prime rate, property prices, consumer consumption expenditure, debt-to-disposable income and the level of unemployment were determinants of the level of over-indebtedness. CPI remained insignificant due to its minimal effects on disposable income. The NCA proved to have a positive significant effect on the levels of over-indebtedness, thus indicating that the NCA had not succeeded in its purposes in reducing the vulnerability of consumers from becoming over-indebted.

The findings of this study hold important implications for regulatory and policy-makers. The current affordability assessment of the NCA requires attention in order to improve its role in assessing the risk profile of consumers. The assessment could for example conduct a form of credit stress testing on consumers during their application for credit. This updated affordability assessment will limit the granting of credit to consumers who are more sensitive to adverse external market shocks, thus creating a healthier consumer credit market and stable financial system in South Africa. Furthermore, it is suggested that more governance and regulations should be implemented in the lending of unsecured loans and micro loans in South Africa, as 
both consumers and credit providers are defeating the purpose of the NCA by exploiting this ungoverned market.

As with all empirical studies, there are some limitations to which a study is subject. Firstly, the exclusion of the non-banking retail credit market affects the scope of the study. Due to limited data available about this industry, it was challenging to measure the size of the retail credit market and the overall level of over-indebtedness in this industry, as data is not publicly available. Secondly, not enough time may have elapsed since the implementation of the NCA to fully capture the long-term effects of the act on the levels of consumer over-indebtedness. For example, there may still be a large number of consumers in the credit market who are highly indebted because of the outdated credit lending regulations prior to the implementation of the NCA. This 'old group' of credit, or riskier consumers, may take a few years to exit the credit system.

Due to the limitations of this study, the following two recommendations for further research are suggested. Firstly, if data is made publicly available or is obtainable from a major credit provider, the same study can be conducted for the retail credit industry and the results be compared to the findings of this study. Secondly, the same study can be repeated in a number of years' time, thus allowing for the 'old credit' to be removed from the system. This could then result in a more accurate account of the effects of the NCA on the levels of over-indebtedness in South Africa.

\section{LIST OF REFERENCES}

Adewale, A.R. (2014). Financial Regulation, Credit Consumption and Economic Growth-An Analysis of the National Credit Act in South Africa. Journal of Applied Business Research (JABR), 30(2), pp. $367-$ 378.

Alan, G. (1996). Can measures of the consumer debt burden reliably predict an economic slowdown? Economic Review, 81 (4), pp. 1-9.

Allison, P. (2012). When can you safely ignore multicollinearity? [On-line] Available: http://www.statisticalhorizons.com/multicollinearity. (Accessed 23 March 2015).

Aron, J., \& Muellbauer, J. (2000). Financial liberalisation, consumption and debt in South Africa. Centre for the Study of African Economies, Department of Economics, University of Oxford.

Arpa, M., Giulini, I., Ittner, A. \& Pauer, F. (2001). The influence of macroeconomic developments on Austrian banks: implications for banking supervision. BIS Papers, 1, pp. 91-116.

Bofondi, M. \& Ropele, T. (2011). Macroeconomic determinants of bad loans: evidence from Italian banks. Bank of Italy Occasional Paper, (89).

Braucher, J. (2006). Theories of overindebtedness: Interaction of structure and culture. Theoretical Inquiries in Law, 7(2), pp. 323-346.

Chipeta, C. \& Mbululu, D. (2012). The effects of the National Credit Act and the global financial crisis on domestic credit extension: Empirical evidence from South Africa. Journal of Economic and Financial Science, 5(1), pp. 215-228.

Compliance and Risk Resources. (2012). Research on the Increase of Unsecured Personal Loans in South Africa's Credit Market. Bryanston: Compliance and Risk Resources. 
Cronje, M. \& Roux, A., (2010). Saving culture for the black middle class in South Africa. USB Leaders Lab, 4(2), pp. 22-27.

Debelle, G. (2004). Household debt and the macro economy. BIS quarterly review, 51, pp. 51-64.

Department of Trade and Industry. (2001). Making Credit Markets Work, A Policy Framework for Consumer Credit. [On-line] Available:

http://www.ncr.org.za/index.php?option=com_content\&view=article\&id=25. (Accessed 2 August 2013).

Department of Trade and Industry. (2003). Credit Law Review. [0n-line] Available: http://www.ncr.org.za/publications/Background_NCA_docs/Summary\%20of\%20Findings.pdf. (Accessed 2 August 2013).

Developmentnomics. (2012). Literature review on the impact of the National Credit Act (NCA) has had on the South Africa's credit market. Midrand: Report prepared for the National Credit Regulator.

Disney, R., Bridges, S. \& Gathergood, J. (2008). Drivers of Over-indebtedness. Report to the UK Department for Business.

Fourie, L., Botha, I. \& Mears, R. (2011). Credit extension in South Africa: A Business cycle perspective for the period 1985 to 2009, Journal of Business Management, 5(34), pp. $13074-13083$.

Goodwin-Groen, R. (2006). The National Credit Act and its regulations in the context of access to Finance in South Africa. Johannesburg: FinMark Trust.

Gujarati, D.N., \& Porter, D.C. (2009). Basic Econometrics, 5th edition. Singapore: McGraw-Hill. Havrylchyk, 0. (2010). A macroeconomic credit risk model for stress testing the South African banking sector. South African Reserve Bank Working Paper, WP/10/02.

Hurwitz, I. \& Luiz, J. (2007). Urban working class credit usage and over-indebtedness in South Africa, Journal of Southern African Studies, 33(1), pp.107-131.

INSOL, (2001). Consumer Debt Report. Report of Findings and Recommendations. London: INSOL International.

Jappelli, T., Pagano, M. \& Di Maggio, M. (2008). Households' indebtedness and financial fragility. CSEF Working Papers, 208.

Kalirai, H. \& Scheicher, M. (2002). Macroeconomic stress testing: preliminary evidence for Austria. Financial Stability Report, 3, pp. 58-74.

Keese, M. (2009). Triggers and Determinants of Severe Household indebtedness in Germany. Ruhr Economic Papers, 150.

Kelly-Louw, M. (2008). The Prevention and Alleviation of Consumer Over-indebtedness. SA Mercantile Law Journal, 20(2), pp. 200-226.

Kelly-Louw, M. (2009). The South Africa National Credit Act fails to protect homeowners against various interest rate hikes. US-Chain Law Review, 6(12), pp. 12-24.

Kotzè, L. \& Smit, A. (2008). Personal finances: What is the possible impact on entrepreneurial activity in South Africa? Southern African Business Review. 12(3), pp. 156-172.

Louzis, D. P., Vouldis, A. T. \& Metaxas, V. L. (2012). Macroeconomic and bank-specific determinants of non-performing loans in Greece: A comparative study of mortgage, business and consumer loan portfolios. Journal of Banking \& Finance, 36(4). pp. 1012-1027. 
Meniago, C., Mukuddem-Petersen, J., Petersen, M.A. \& Mongale, I.P. (2013). What causes household debt to increase in South Africa? Economic Modelling, 33, pp. 482-429.

Modigliani, F. \& Brumberg, R. (1954). Utility analysis and the consumption function: An interpretation of cross-section data. FRANCO MODIGLIANI, 1 .

Montgomery, D.C., Peck, E.A. \& Vining, G. (2001). Introduction to Linear Regression Analysis. Wiley: New York

National Credit Regulator. (2014). Credit Bureau Monitor, First Puarter March 2014. [Online] Available: www.ncr.org.za. (Accessed 19 June 2014).

Nieto, F. (2007). The determinants of house hold credit in Spain. Madrid: Bank of Span.

Otto, J. (2010). The history of consumer credit legislation in South Africa. Fundamina: A Journal of Legal History: Libellus ad Thomasium: Essays in Roman Law, Roman-Dutch Law and Legal History in Honour of PhilipJ Thomas. 16(1), pp. 257-273.

Park, S. (1993). The Determinants of Consumer Instalment Credit, Federal Reserve Bank of St. Louis Review. 75(November/December), pp. 23-38.

Renke, S. (2011). Measures in South African consumer credit legislation aimed at the prevention of reckless lending and over-indebtedness: an overview against the background of recent developments in the European Union. Journal of Contemporary Roman-Dutch Law, 74(208). pp. 1-21.

Rinaldi, L. \& Sanchis-Arellano, A. (2006). Household debt sustainability. What explains household non-performing loans? An empirical analysis. European Central Bank Working Paper Series, 570.

Rubaszek, M. \& Serwa, D. (2012). Determinants of credit to households in a Life-cycle Model, European Central Bank Working Paper Series, 1420.

SARB. (2000). Bank Supervision Department Annual Report. Pretoria: South African Reserve Bank. SARB. (2001). Bank Supervision Department Annual Report. Pretoria: South African Reserve Bank. SARB. (2008). Bank Supervision Department Annual Report. Pretoria: South African Reserve Bank. SARB. (2014). Quarterly Bulletin, No. 272. Pretoria: South African Reserve Bank.

Schicks, J. (2010). Microfinance Over-Indebtedness: Understanding its drivers and challenging the common myths. Bruxelles: Centre Emilee Bergheim, Solvay School of Business, CEB Working Paper, 10(048).

Shu, C. (2002). The impact of macroeconomic environment on the asset quality of Hong Kong's banking sector. Hong Kong Monetary Authority Research Memorandum, (20).

Simovic, V., Vaskovic, V., Rankovic, M. \& Malinic, S. (2011). The impact of the functional characteristics of a credit bureau on the level of indebtedness per capita: Evidence from East European countries. Baltic Journal of Economics, 11(2), pp. 101-130.

South Africa (Republic). (2006). National Credit Act, No. 34 of 2005. Government Gazette no. 28619, 489.

South Africa (Republic). (2011). A safer financial sector to serve South Africa better. Pretoria: National Treasury.

South Africa (Republic). (2012). Banks ACT, 1990 (ACT N0.94 OF 1990) regulation relation to banks, Government Gazette no. 35905, 570. 
STATS SA. (2011). Statistical release (Revised) Census 2011. [0nline] Available: http://www.statssa.gov.za/publications/P03014/P030142011.pdf. (Accessed 7 July 2014).

Stoop P.N. (2009). South African Consumer Credit Policy: Measures indirectly aimed at Preventing Consumer Over-Indebtedness. SA Mercantile Law Journal, 21(3), pp. 365-386.

Vessio, M.L. (2009). Beware the provider of reckless credit, Tydskrif vir die Suid-Akrikaanse Reg, (2), pp. 274-289.

Virolainen, K. (2004). Macro stress testing with a macroeconomic credit risk model for Finland. Bank of Finland discussion paper, (18).

Zeman, J. \& Jurca, P. (2008). Macro stress testing of the Slovak banking sector. National bank of Slovakia working paper, 1 . 